\title{
PERSEPSI MASYARAKAT LOKAL TERHADAP PERAN KOMUNITAS LGBT DALAM MENDUKUNG PARIWISATA DI BALI - STUDI KASUS DI KELURAHAN SEMINYAK, KUTA
}

\author{
Windy Wijaya \\ Sekolah Tinggi Pariwisata Bali International, Denpasar \\ Email : windywijaya44@gmail.com
}

\begin{abstract}
Bali is one of the islands in Indonesia which is the largest income contributor in Indonesia in the tourism sector. Bali is famous for culture-based tourism. But the fact is that many tourists who come to Bali are looking for night attractions. Night tourism can be said as a new lifestyle attached to the island of Bali. Not only tourists who enjoy night tours but local people also fully participate in enjoying the attraction. With the freedom of life in Bali, the clubs began to emerge specifically for LGBT people. LGBT is an act that opposes Balinese religion and culture. However, the government and the community around the LGBT clubs did not care about this. This study aims to find out the perceptions of local communities in Seminyak-Kuta areas towards LGBT's contribution in tourism sector in Bali.
\end{abstract}

\begin{abstract}
Abstrak
Bali merupakan salah satu pulau di Indonesia yang merupakan penyumbang pendapatan terbesar di Indonesia dalam sektor pariwisatanya. Bali terkenal dengan pariwisata yang berbasis budaya. Namun faktanya banyak wisatawan yang datang ke Bali justru mencari atraksi wisata malamnya. Wisata malam dapat dikatakan sebagai gaya hidup baru yang melekat pada pulau Bali. Tidak hanya wisatawan yang menikmati wisata malam melainkan masyarakat lokal juga ikut dalam menikmati atraksi tersebut. Dengan bebasnya kehidupan di Bali, maka mulailah bermunculan club-club khusus untuk kaum LGBT. Perilaku LGBT umumnya bertentangan dengan agama dan budaya Bali. Akan tetapi pemerintah dan masyarakat sekitar club-club LGBT tersebut tidak mempedulikan hal tersebut. Studi ini bertujuan untuk mengetahui persepsi masyarakat lokal di daerah seminyak terhadap peran komunitas LGBT dalam mendukung pariwisata di Bali..
\end{abstract}

\section{PENDAHULUAN}

Menurut Undang-undang no 10 tahun 2009 tentang Kepariwisataan, Pariwisata adalah "Berbagai macam kegiatan wisata dan didukung fasilitas serta layanan yang disediakan masyarakat setempat, sesama wisatawan, pemerintah, pemerintah daerah dan pengusaha". Di Indonesia, Pariwisata Merupakan salah satu industri terbesar yang menyumbangkan pendapatan atau devisa terbesar ke dua setelah Industri kelapa Sawit.

Pariwisata di Indonesia memiliki berbagai potensi yang sangat baik, hal ini dapat dilihat dari 742 bahasa, 300 etnik yang memiliki budaya yang berbeda-beda dan unik di Indonesia. Pariwisata Indonesia saat ini masih bergantung pada pariwisata Bali dan tingkat kunjungan yang 
ada di Pulau Bali, karena sampai saat ini pulau Bali adalah penyumbang Pendapatan Terbesar di Sektor pariwisata Indonesia.

Saat ini pemerintah Indonesia sedang gencar-gencarnya mengembangkan pariwisata Indonesia yang dimana atraksi wisata yang dimiliki Pariwisata Indonesia lebih dominan adalah wisata heritage dan alam. Pengembangan pariwisata dilakukan pemerintah dengan cara membangun 10 Bali baru. Untuk mengembangkan pariwisatanya, saat ini Indonesia sudah mulai mengembangkan wisata buatan sebagai daya tarik wisata. Contoh nya di Bali yang merupakan pusat pariwisata di Indonesia.

Di Bali sendiri banyak masyarakat yang menggantungkan hidupnya pada industri pariwisata, karena Bali sendiri terkenal dengan memiliki banyak potensi wisata seperti alam dan budaya. Tetapi saat ini Bali mulai membangun berbagai wisata buatan seperti Club-club malam, Bar dan Café. Dengan ada nya pembangunan wisata buatan tersebut, hal ini membuat para wisatawan baik itu wisatawan mancanegara maupun domestic mulai memiliki tujuan atau motivasi baru saat mengunjungi Bali, potensi wisata buatan ini biasa disebut wisata malam atau yang dikenal dengan night life (tempat hiburan malam atau club) yang menjadi salah satu cara untuk menarik jumlah kunjungan wisatawan agar semakin meningkat. Wisata malam ini biasanya identik dengan kegiatan yang bersifat gembira, berpesta, identik dengan musik dan tentunya minuman alcohol. Dengan bebas nya kehidupan di Bali, maka semakin banyak bermunculan club-club maupun tempat-tempat hiburan di Bali. Dan juga akan berdampak pada degradasi budaya di Bali.

Dari sini juga mulai muncul club-club khusus yang di peruntukan untuk kaum LGBT. LGBT adalah Lesbian, Gay, Biseksual, Transgender, yang dimana istilah ini biasa nya digunakan untuk semua orang yang tidak heteroseksual atau orang-orang yang menyukai sesama jenis. Dalam sisi Hukum di Indonesia memang belum ada peraturan mengenai LGBT dikarenakan hukum tindak pidana Indonesia sampai saat ini tidak menganggap perbuatan homoseksual sebagai sebuah tindakan kriminal.(Yudhistira Dharma, 2016)

Akan tetapi hal ini tentu bertolak belakang dengan budaya hidup Bali. Dimana Wakil ketua PHDI Bali, Drs. Mangku Pasek Swastika dalam fokus grup diskusi yang digelar himpunan jurusan Mahasiswa Fakultas Brahmana Widya, IHDN Denpasar berpendapat bahwa menurut nya berdasarkan kitab Manawa Dharma Sastra yang merupakan kitab suci Bali, LGBT tidak lah di benarkan. "Menurut kitab-kitab rujukan yang say abaca, LGBT merupakan penyimpangan dan tidak sesuai dengan sabda Tuhan. Seperti yang tertera dalam Manawa Dharma Sastra IX,96”. 
(Drs. Mangku Pasek Swastika, 2018). Dan merujuk ke Undang-Undang Perkawinan nomor 1 tahun 1974 pasal 1 menyatakan bahwa perkawinan ialah ikatan lahir batin antara seorang pria dengan seorang wanita sebagai suami isteri dengan tujuan membentuk Keluarga (rumah tangga) yang bahagia dan kekal berdasarkan Ketuhanan Yang Maha Esa.(Hukum Online, 2018) Namun, fakta nya di lapangan justru banyak club-club atau tempat hiburan malam yang dikhususkan untuk kaum LGBT, saat ini club-club tersebut juga sudah mulai merambah pariwisata di Bali khususnya di jalan Camplung Tanduk di daerah Seminyak. Walaupun penyimpangan ini terjadi tetapi pemerintah Bali tidak melakukan tindakan.

Menurut forum M.Merdeka.com, Bali lebi tepat nya di Jalan Camplung Tanduk ini merupakan surga nya para kaum Homoseksual, karena di panjang jalan Camplung Tandul ini berdiri club-club maupun bar-bar yang dikhususkan untuk para kaum Homoseksual atau Gay.(Wisnoe Moerti, 2016). Walaupun banyak bermunculan club-club khusus untuk homoseksual tersebut, akan tetapi masyarakat sekitar daerah tersebut seperti tidak melakukan tindakan-tindakan untuk mencegah hal tersebut.

Dari sinilah Peneliti merasa tertarik untuk menelusuri dan melihat bagaimana persepsi masyarakat sekitar jalan Camplung tersebut terhadap berjalan nya club-club maupun tempat hiburan malam yang dikhususkan untuk kaum LGBT tersebut.

\section{METODE PENELITIAN}

Lokasi penelitian ini dilaksanakan di daerah Seminyak tepat nya di jl.Camplung Tanduk karena di daerah ini dibangun tempat hiburan malam yang dikhususkan untuk kaum LGBT seperti Bali Joe, Mixwell Bar,Face Bar dll. Adapun jarak jalan Camplung Tanduk no. 8 ini dari kota Denpasar adalah $8.4 \mathrm{Km}$ yang dapat ditempuh dalam waktu 30 menit. Penelitian pendahuluan ini dilaksanakan pada bulan Desember 2018. Pengambilan data dilakukan dengan cara purposive sampling dimana dilakukan wawancara kepada beberapa masyarakat. Analisis penelitian ini melakukan analisis deskriptif kualitatif untuk menjelaskan data-data yang sudah didapat melalui teknik wawancara dan juga observasi.

\section{HASIL DAN PEMBAHASAN}

Untuk menggambarkan persepsi masyarakat daerah Seminyak maka digunakan teori sikap masyarakat. Berikut adalah tahapan masyarakat yang dikembangkan oleh Doxey dan digambarkan oleh Fridgen (Suwono dkk,2011) : 


\section{a. Euphoria}

Pada masa awal pengembangan, masyarakat menyambut baik kedatangan wisatawan dan mengambil manfaat ekonomi dari kegiatan wisata yang berkembang. Karena dengan adanya pariwisata masyarakat langsung dapat berinteraksi dengan wisatawan dan mendapat keuntungan langsung.

b. Apathy

Tahapan dimana ketika kunjungan semakin meningkat dan beberapa perubahan terjadi pada lingkungan tempat tinggal masyarakat, masyarakat mulai menunjukan sikap negative dan wisatawan memilih tidak tinggal lama di lingkungan tersebut.

Dengan banyaknya kunjungan wisatawan, masyarakat mulai terbiasa dengan wisatawan serta menganggap kunjungan wisatawan sudah biasa, sehingga masyarakat mulai acuh tak acuh terhadap wisatawan. Yang dimana hal ini menjadikan wisatawan merasa kurang mendapat perlakuan dari masyarakat yang ramah tamah dan menjadikan wisatawan tidak nyaman berada di daerah tujuan wisata.

c. Annoyance

Pertumbuhan pariwisata terus terjadi, masyarakat menjadi terus tersisih karena semakin banyaknya wisatawan yang datang dan perhatian berbagai pihak diberikan hanya untuk pariwisata. Dimana masyarakat mulai menganggap wisatawan hanya sebagai objek komersial.

\section{d. Antagonism}

Destinasi telah tumbuh menjadi destinasi pariwisata masal. Masyarakat tidak lagi menyambut dengan baik wisatawan, jauh dari sikap dan membantu. Pada tahap ini biasanya jenis wisatawan yang datang akan berubah. Masyarakat mulai terganggu dengan hadirnya wisatawan.

Dari penelitian yang dilakukan di Seminyak-Kuta yang menjadi area populer tempat berkumpulnya komunitas LGBT (Lesbian, Gay, Biseksual, Transgender) di Bali, ternyata peran komunitas ini telah memberikan dampak positif dalam mendongkrak pariwisata Bali. Hal ini dikarenakan kaum LGBT mendatangkan teman-teman sesama LGBT ke Bali untuk bersosialisasi langsung. Komunitas LGBT di Bali juga sering membuat sebuah event ataupun acara dalam 
menarik pengunjung datang ke sebuah acara pertunjukan yang sering mereka selenggarakan seperti event Drag Queen dan lain-lain.

Di kalangan masyarakat Indonesia, perilaku kaum LGBT ini banyak mendapat tentangan, cemoohan dan penolakan. Namun keberadaan mereka di Indonesia yang multikultur ini merupakan sebuah keniscayaan. Di kalangan mereka sendiri berpendapat bahwa tidak semua kaum LGBT tersebut memiliki perilaku yang menyimpang. Ada sisi positif yang dapat disumbangkan oleh mereka dalam mempertahankan eksistensinya di masyarakat. Beberapa hal positif yang dilakukan antara lain mengkreasi sebuah pagelaran seni kontemporer, penyelenggaraan eksebisi pengolahan kuliner, lomba kecantikan, dan lain lain.

Masyarakat Bali yang terkenal religius dan kental akan budayanya, dengan perkembangan pariwisatanya, tidak dapat menampik keberadaan kaum LGBT ini di Bali. Istilah LGBT ini sudah lama digunakan sejak tahun 90an. Penelitian lebih banyak dilakukan oleh para psikiater dan mengartikan bahwa homoseksual maupun heteroseksual merupakan penyakit mental dan kelainan mental.

Terhadap peran komunitas LGBT di Seminyak-Kuta, ternyata bahwa persepsi masyarakat bervariasi. Sebagian besar menolak perilaku kaum LGBT. Namun peran mereka dalam penyelenggaraan event dan kegiatan yang dapat mendukung kepariwisataan mendapat dukungan dari sebagian kelompok masyarakat.

\section{KESIMPULAN}

Perilaku kaum LGBT merupakan suatu bentuk penyimpangan yang bertolak belakang dengan budaya Bali. Akan tetapi peran LGBT ini justru juga memberikan dampak yang positif dalam mendongkrak pariwisata di Bali. Hal ini dapat dilihat dari adanya wisatawan-wisatawan yang datang mengunjungi club-club LGBT. Dengan adanya penyimpangan seperti ini, masyarakat lokal justru bersikap tidak mempedulikan hal tersebut. Setelah dilakukan wawancara dengan beberapa masyarakat di daerah seminyak, dapat disimpulkan bahwa ada yang memang setuju dengan adanya club-club LGBT ini, ada juga yang tidak setuju dengan ada nya club tersebut. Pihak yang setuju memiliki alasan bahwa hal tersebut selama tidak mengganggu warga sekitar maka tidak masalah. Kalangan masyarakat yang tidak setuju sebagian besar memberikan alasan bahwa hal tersebut merupakan tindakan negatif yang dapat berdampak bagi kepribadian generasi-generasi muda. 


\section{DAFTAR PUSTAKA}

Chandra, Ardan Adhi.2017. Tiga tahun Jokowi-JK, Pariwisata Sumbang devisa terbesar kedua. Sumber : https://finance.detik.com/berita-ekonomi-bisnis/d-3687715/tiga-tahun-jokowi-jkpariwisata-sumbang-devisa-terbesar-kedua : diakses pada tanggal 03 October 2018

Krisdianto,D. 2017. Konsepsi Lesbian, Gay, Biseksual dan Transgender ( LGBT) perspektif jaringan Islam Liberal (JIL). Sumber : http://digilib.uinsby.ac.id/19559/3/Bab\%202.pdf : diakses pada tanggal 03 October 2018

Meyers,Koen.2009. Pengertian Pariwisata.Sumber : http://www.spengetahuan.com/2015/12/20pengertian-pariwisata-menurut-para-ahli-terlengkap.html : diakses pada tanggal 27

September 2018

Pitana, IG.1999. Pelangi Pariwisata Bali- Kajian Aspek Sosial Budaya Kepariwisataan Bali di Penghujung Abad. Penerbit BP. Denpasar

Priherdityo, Endro. 2016. Seminyak Bali, Daerah Wisata Ramah Bagi Kaum LGBT. Sumber : https://www.cnnindonesia.com/gaya-hidup/20161021181904-269-167082/seminyak-balidaerah-wisata-ramah-bagi-kaum-lgbt : diakses pada tanggal 03 October 2018

Robbins. 2003. Pengertian Persepsi Menurut Para Ahli. http://belajarpsikologi.com/pengertianpersepsi-menurut-ahli/ : 27 September 2018

Sarwono. 2009. Pengertian Persepsi Sumber http://digilib.unila.ac.id/3680/16/BAB\%20II.pdf : diakses pada tanggal 27 September 2018

Subandy. 1997. Pengertian Wisata Malam. Sumber : http://digilib.unila.ac.id/26071/2/SKRIPSI\%20TANPA\%20BAB\%20PEMBAHASAN.pdf : diakses pada tanggal 27 September 2018

Sugihartono,dkk. 2007. Psikologi Pendidikan. Yogyakarta: UNY Press. Loa,Andrian. 2016. Kebijakan Antisipasi terhadap masalah apathy, irritation, dan antagonism dari masyarakat terhadap wisatawan. Sumber : https://adrianhartantolokaria.wordpress.com/2016/05/27/kebijakan-antisipasi-terhadapmasalah-apathy-irritation-dan-antagonism-dari-masyarakat-terhadap-wisatawan/: diakses pada tanggal 3 October 2018

Sutiarso MA, KTP Arcana, NPE Juliantari, IMB Gunantara. 2018. Strategi Pengembangan Pariwisata Berbasis Budaya di Desa Selumbung, Karangasem. Jurnal Pariwisata Budaya, Volume 3 No 2, Hal 15-23. 